\title{
Elevation of Pediococcus cerevisiae subsp. dextrinicus Coster and White to Species Status [Pediococcus dextrinicus (Coster and White) comb. nov.]
}

\author{
WERNER BACK \\ Döhler GmbH \& Co KG, Mikrobiologische Abteilung, 6100 Darmstadt, Germany
}

\begin{abstract}
Studies on 15 dextrin-fermenting, L-(+)-lactic acid-producing pediococci, including two strains originally described in 1964 by Coster and White under the name Pediococcus cerevisiae var. (= subsp.) dextrinicus, and 13 new isolates from beer, beer bottles, silage, and spent grains showed that these strains represent a distinct, well defined species. This species can be distinguished from all other pediococci by the following: its carbohydrate fermentation, especially starch hydrolysis; the electrophoretic mobility of its lactate dehydrogenase; and the production of a fructose-1,6-diphosphate-activated $\mathrm{L}$-lactate dehydrogenase. In this paper, $P$. cerevisiae subsp. dextrinicus is elevated to the rank of species. The name of this species is Pediococcus dextrinicus (Coster and White) comb. nov. strain DSM 20335 is designated as the type strain of $P$. dextrinicus. A culture of this strain has been deposited in the Deutsche Sammlung von Mikroorganismen, Germany.
\end{abstract}

Günther and White $(3,4)$ isolated 14 strains of dextrin-fermenting pediococci from silage and placed them in their group III of the genus Pediocorcus. The strains differed from each other in their fermentation of fructose, maltose, lactose, salicin, arabinose, and xylose, in their production of acid in litmus milk, and in their abilities to grow in the presence of $6.5 \% \mathrm{NaCl}$. Coster and White (2) proposed the name Pediococcus cerevisiae var. dextrinicus for the strains of group III. However, because of their serological properties and their ability to form dextrorotatory lactic acid, Coster and White (2) suggested that these strains may well represent a separate species. Moreover, 13 strains isolated by the author from beer, beer bottles, silage, and spent grains exhibited characteristics similar to those of the above-mentioned organisms. Four strains of these were regarded by the author (W. Back, Ph.D. thesis, Technische Universität München, Munich, Germany, 1974) as members of $P$. cerevisiae var. (= subsp.) dextrinicus, which the author elevated to the rank of a species, $P$. dextrinicus. However, this proposal was made in a dissertation and was thus not effectively published. The purpose of this paper is to effect the valid publication of the name $P$. dextrinicus (Coster and White) comb. nov. and to provide a description of this species.

\section{MATERIALS AND METHODS}

Bacterial strains. Strains L22 (= National Collection of Dairy Organisms [NCDO] 1249) and L95 (= NCDO 1561 = Deutsche Sammlung von Mikroorgan- ismen [DSM] 20335) were isolated by Günther and White (3) from silage. They are two of the strains of group III on which the original description of $P$. cerevisiae subsp. dextrinicus (2) was based. Further strains of this group were not available. The other strains studied were isolated by the author from beer (B315b [= DSM 20293] and B371a), from beer bottles (B150a, B151b), from silage (S2a, S2b, S14a, BS1b, BS7a, BS8a), or from spent grains (T3a, T3c, T5a).

Media and methods. Except as noted below, the media and methods used were previously described by Back (1). Descriptions of the methods used to characterize the genotype by means of deoxyribonucleic acid (DNA)-DNA homology were described by Back and Stackebrandt (1a).

The guanine-plus-cytosine $(\mathrm{G}+\mathrm{C})$ content of the DNA was determined from the mean melting temperature as described by Marmur (7). The bacterial cells, however, were disrupted in a cell mill (Bühler) with glass beads, and the precipitated DNA was collected by centrifugation.

Cell walls were prepared and analyzed as described by Schleifer and Kandler (8). The type of peptidoglycan is given in the notation system of Schleifer and Kandler (9).

\section{RESULTS AND DISCUSSION}

Description of Pediococcus dextrinicus comb. nov. (Pediococcus cerevisiae var. dextrinicus Coster and White 1964, 29; Pediococcus dextrinicus Back 1974, 78-84.) dex.tri'ni.cus. M.L.adj. dextrinicus dextrin; relating to dextrin fermentation.

Based on their morphology, mode of division, cell wall composition, $\mathrm{G}+\mathrm{C}$ content of the DNA, homofermentative lactic acid production, and 
nutritional requirements, the strains studied here were placed in the genus Pediococcus (6). The following description of $P$. dextrinicus is based on 15 phenotypically and genotypically well characterized strains.

Spheres, 0.8 to $1.1 \mu \mathrm{m}$ in diameter, occurring predominantly in pairs and tetrads, occasionally in short chains and irregular clusters. Gram-positive. Nonmotile and non-spore forming.

Surface colonies on MRS agar (2a): raised to slightly convex, circular, entire, 0.5 to $2.5 \mathrm{~mm}$ in diameter, smooth, glistening, opaque, and unpigmented. Mucoid colonies were not formed on MRS agar containing 5\% sucrose. Good growth in MRS broth between 16 and $24 \mathrm{~h}$ and in MRS agar stab culture after $48 \mathrm{~h}$ at $28^{\circ} \mathrm{C}$.

Four strains isolated from beer and beer bottles showed good growth in unhopped wort and moderate growth in weakly hopped beer.

Growth occurred both aerobically and under a $\mathrm{CO}_{2}$ atmosphere. All strains grew at 8 (slow) and at $43^{\circ} \mathrm{C}$ (six strains grew weakly), and four strains grew weakly at $45^{\circ} \mathrm{C}$. The temperature for optimal growth ranged between 30 and $35^{\circ} \mathrm{C}$. All of the strains failed to grow above $45^{\circ} \mathrm{C}$. All of the strains showed good growth at the $\mathrm{NaCl}$ concentrations tested up to $5.5 \%$; up to $6 \% \mathrm{NaCl}$, 10 strains showed good growth; the 5 others showed moderate growth; all of the strains failed to grow at $6.5 \% \mathrm{NaCl}$. Growth took place between pH 4.7 and 8.3. The four strains isolated from beer and beer bottles showed growth at $\mathrm{pH}$ 4.3; 8 other strains grew weakly at $\mathrm{pH} 4.5$. None of the strains grew at $\mathrm{pH} 4.0$ and 8.6. The $\mathrm{pH}$ of MRS broth was lowered from 6.4 to between 3.9 and 4.3. Four strains isolated from beer and beer bottles lowered the pH of wort from 5.8 to 3.8.

All strains were negative for the catalase and benzidine tests. None of the strains reduced nitrate, liquefied gelatin, or produced urease. Litmus milk was changed slightly by some strains (acid by nine strains and reduction by seven strains). All strains failed to produce ammonia from arginine and to hydrolyze hippurate. Esculin and starch were hydrolyzed. There was no production of $\mathrm{CO}_{2}$ from glucose and maltose. Acetylmethylcarbinol was weakly produced by only two strains. These organisms are homofermentative, $L-(+)$-lactic acid being the main product from glucose.

All strains produced acid from glucose, fructose, mannose, galactose, maltose, cellobiose, maltotriose, dextrin, starch (two strains slowly), salicin, amygdalin, and sodium gluconate (acid and gas). Sucrose was fermented by 11 strains (four strains weakly); $\alpha$-methyl-D-glucoside was fermented by 10 strains (four strains weakly and slowly); lactose was fermented by six strains (one strain weakly); trehalose was fermented by four strains (three strains slowly); and inulin was fermented by four strains (one strain weakly and slowly). No acid was produced from arabinose, xylose, ribose, rhamnose, sorbose, melibiose, melezitose, raffinose, glycerol, mannitol, sorbitol, meso-inositol, meso-dulcitol, xylitol, adonitol, erythritol, or galacturonate.

The electrophoretic mobility (polyacrylamide disc electrophoresis) of the L-lactate dehydrogenase (L-LDH) compared with that of the LDH from rabbit muscle ranged between 0.95 and 1.10 (four strains tested). A specific D-LDH could not be demonstrated. The strains contained an L-LDH which is activated by fructose-1,6-diphosphate.

Three strains tested contained cell wall peptidoglycan of type L-Lys-D-Asp.

The $\mathrm{G}+\mathrm{C}$ content of the DNA, as determined for two strains, was $40.3 \pm 0.3 \mathrm{~mol} \%$.

The variable characters of 15 strains of $P$. dextrinicus are shown in Table 1.

Description of the type strain of $P$. dextrinicus. Strain DSM 20335, originally designated L95 by Günther and White (3), is the type strain of $P$. dextrinicus. A description of this strain follows.

Gram-positive, spherical cells, about $1.0 \mu \mathrm{m}$ in diameter, occurring singly, in pairs, and in tetrads, occasionally in short chains and irregular clusters. Nonmotile. Endospores not produced.

Agar colonies: low convex, circular, entire, smooth, opaque, grayish-white, glistening, about $1 \mathrm{~mm}$ in diameter. Growth in MRS agar stab culture occurred throughout the entire length of the stab, with a small amount of surface growth. There was abundant growth in MRS broth after $20 \mathrm{~h}$ at $28^{\circ} \mathrm{C}$. Slime was not produced.

Facultatively anaerobic. Optimal growth temperature: about $32^{\circ} \mathrm{C}$. Growth occurred at 8 and at $43^{\circ} \mathrm{C}$, at $\mathrm{pH} 4.5$ (weak) and 8.3 , and in the presence of $6 \% \mathrm{NaCl}$. No growth occurred at $45^{\circ} \mathrm{C}$, at $\mathrm{pH} 4.3$ and 8.6 , or in the presence of 6.5\% NaCl. The final $\mathrm{pH}$ in MRS broth was 3.95.

Catalase was not produced (in the presence of 0.05 and $2 \%$ glucose). The benzidine test was negative. Nitrate was not reduced to nitrite or nitrogen gas. Gelatin was not liquefied. Urease was not produced. Litmus milk was slightly changed (acidified and reduced). Ammonia was not produced from arginine. Esculin and starch were hydrolyzed, but hippurate was not. The Voges-Proskauer test was negative. $\mathrm{CO}_{2}$ was not produced from glucose or maltose. Homofermentative, producing $L-(+)$-lactic acid.

Acid was produced from glucose, fructose, mannose, galactose, maltose, cellobiose, trehalose (slowly), sucrose (slowly), maltotriose, dex- 


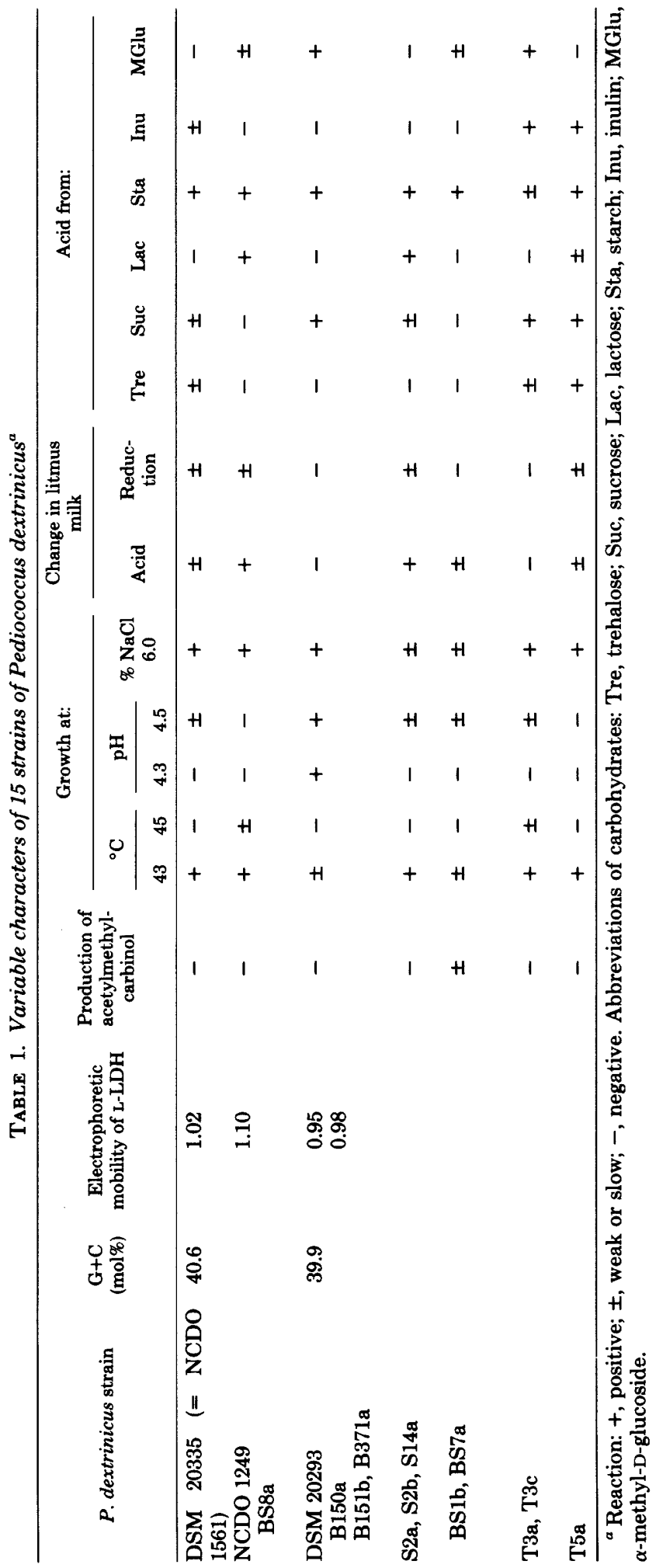


trin, starch, inulin (slowly), salicin, amygdalin, and sodium gluconate (acid and gas). No acid was produced from arabinose, xylose, ribose, rhamnose, sorbose, lactose, melibiose, melezitose, raffinose, glycerol, mannitol, sorbitol, mesoinositol, meso-dulcitol, xylitol, adonitol, erythritol, $\alpha$-methyl-D-glucoside or galacturonate.

The electrophoretic mobility of the L-LDH compared with that of the LDH of rabbit muscle was 1.02. The activity of the L-LDH was increased 20-fold by fructose-1,6-diphosphate. A specific D-LDH could not be demonstrated.

The cell wall peptidoglycan was of the L-LysD-Asp type.

The G+C content of the DNA was 40.6 $\mathrm{mol} \%$.

DNA-DNA hybridization: On the basis of DNA/DNA homology (4 to 8\%), strain DSM 20335 showed only a slight genetic relationship to all other known species of the genus Pediococcus (1a). The reassociation data between strain DSM 20335 and representative strains of various species of the genus Pediococcus are listed in Table 2.

$P$. dextrinicus seems to be very uncommonly found in nature. Besides the 27 strains mentioned in this paper, only one strain with similar characters has been reported in the literature. This strain (S-4), isolated from a Norwegian brewery, was studied by Solberg and Clausen (10) and was first identified as a member of $P$. cerevisiae var. (= subsp.) dextrinicus. Despite the relatively small number of known strains of this organism, there is no question as to its uniqueness.

$P$. dextrinicus can be distinguished from the strains of $P$. cerevisiae studied by Coster and White (2) by its carbohydrate reaction pattern, especially by its fermentation of dextrin and starch and by its inability to ferment pentoses and hydrolyze arginine. In addition, $P$. dextrinicus differs from $P$. cerevisiae and from all other pediococci by the electrophoretic mobility of its fructose-1,6-diphosphate-activated LLDH. It is primarily on this basis that $P$. cerevisiae subsp. dextrinicus is here elevated to species rank.

In contrast to other pediococci (6), $P$. dextrinicus is able to hydrolyze starch. This species also differs from nearly all other pediococci by fermenting dextrin and by producing $L(+)$-lactic acid. $P$. dextrinicus differs from $P$. pentosaceus, $P$. acidilactici, and $P$. halophilus by its inability to ferment pentoses, to produce ammonia from arginine, and to grow at $\mathrm{NaCl}$ concentrations above $6.5 \%$. It differs from $P$. dumnosus (5) and from $P$. parvulus by its growth at $42^{\circ} \mathrm{C}$ and $\mathrm{pH}$ 8.0 and by its inability to grow at $\mathrm{pH}$ 4.2. Finally, $P$. dextrinicus is distinguished from $P$. urinaeequi, which contains a different cell wall pepti-

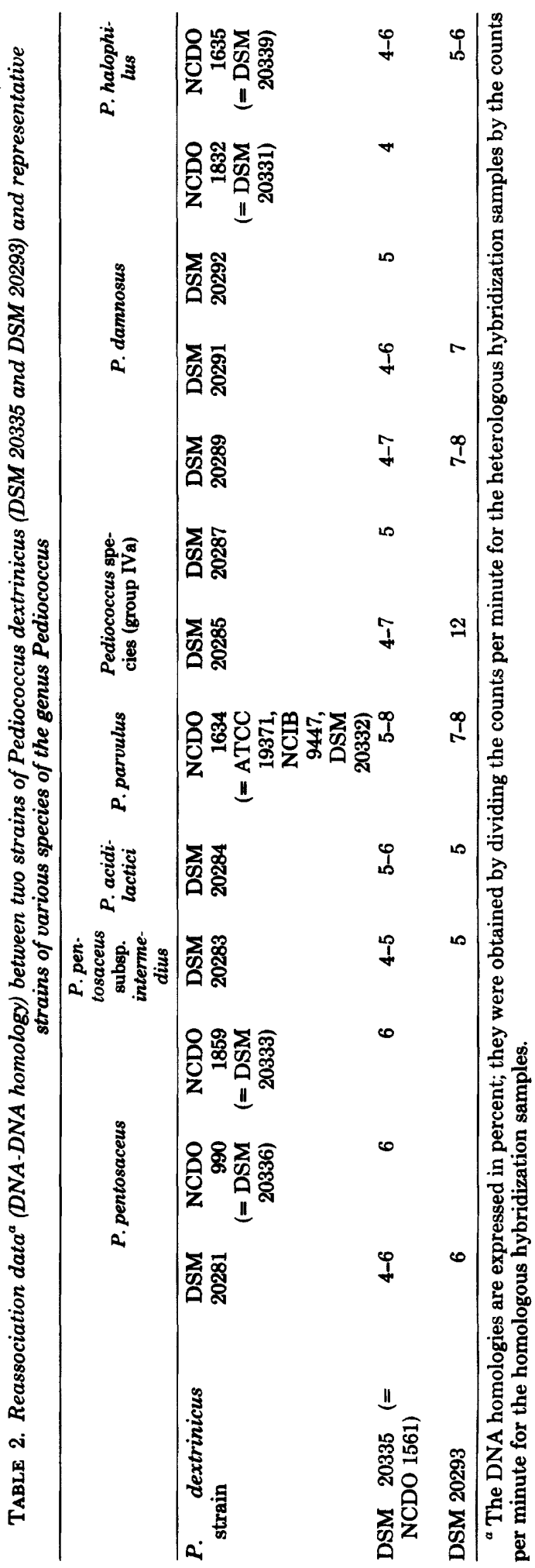


doglycan (Back and Weiss, manuscript in preparation), by its growth at $42^{\circ} \mathrm{C}$ and $\mathrm{pH} 5.0$, by its inability to grow at $\mathrm{pH} 8.6$, and by its relatively high acid production.

The phenotypic distinctiveness of $P$. dextrinicus was confirmed by the results of genotypic studies. Thus, the low DNA-DNA homology rates between two strains of $P$. dextrinicus (DSM 20293, DSM 20335) and various strains of the species $P$. pentosaceus, $P$. acidilactici, $P$. parvulus, $P$. damnosus, and $P$. halophilus indicate only a distant relationship between $P$. dextrinicus and the other pediococci (Table 2).

\section{ACKNOWLEDGMENT}

The author is greatly indebted to $O$. Kandler for permitting much of the work to be performed at the Botanical Institute of the University of Munich.

\section{REPRINT REQUESTS}

Address reprint requests to: Dr. Werner Back, Döhler GmbH \& Co KG, Mikrobiologische Abteilung, Riedstrasse 9, 6100 Darmstadt, BRD, Germany.

\section{LITERATURE CITED}

1. Back, W. 1978. Zur Taxonomie der Gattung Pediococcus. Phänotypische und genotypische Abgrenzung der bisher bekannten Arten sowie Beschreibung einer neuen bierschädlichen Art: Pediococcus inopinatus. Brauwissenschaft 31:237-250.

1a. Back, W., and E. Stackebrandt. 1978. DNS/DNS-
Homologiestudien innerhalb der Gattung Pediococcus. Arch. Microbiol. 118:79-85.

2. Coster, E., and H. R. White. 1964. Further studies of the genus Pediococcus. J. Gen. Microbiol. 37:15-31.

2a. De Man, J. C., M. Rogosa, and M. E. Sharpe. 1960. A medium for the cultivation of lactobacilli. J. Appl. Bacteriol. 23:130-135.

3. Günther, H. L., and H. R. White. 1961. The cultural and physiological characters of the pediococci. J. Gen. Microbiol. 26:185-197.

4. Günther, H. L., and H. R. White. 1961. Serological characters of the pediococci. J. Gen. Microbiol. 26:199-205.

5. Judicial Commission of the International Committee on Systematic Bacteriology. 1976. Opinion 52. Conservation of the generic name Pediococcus Claussen with the type species Pediococcus damnosus Claussen. Int. J. Syst. Bacteriol. 26:292.

6. Kitahara, K. 1974. Genus III. Pediococcus Balcke 1884, 257, p. 514. In R. E. Buchanan and N. E. Gibbons (ed.), Bergey's manual of determinative bacteriology, 8 th ed. The Williams \& Wilkins Co., Baltimore.

7. Marmur, J. 1961. A procedure for the isolation of deoxyribonucleic acid from micro-organisms. J. Mol. Biol. 3:208-218.

8. Schleifer, K. H., and O. Kandler. 1967. Zur chemischen Zusammensetzung der Zellwand der Streptokokken. I. Die Aminosäuresequenz des Mureins von Streptococcus thermophilus und Streptococcus faecalis. Arch. Mikrobiol. 57:335-364.

9. Schleifer, K. H., and O. Kandler. 1972. The peptidoglycan types of bacterial cell walls and their taxonomic implications. Bacteriol. Rev. 36:407-477.

10. Solberg, O., and O. G. Clausen. 1973. Classification of certain pediococci isolated from brewery products. $\mathrm{J}$. Inst. Brew. 79:227-230. 